\title{
How Do Villagers Solve Their Legal Problems? A Study of District Court (Peradilan Desa) for Dispute Settlement Process
}

\author{
Rofi Wahanisa ${ }^{1}$, Dwi Lestari ${ }^{3}$, Malik Akbar Mulki Rahman³, Fadhilah Rizky \\ Aftriani Putri ${ }^{4} \bowtie$ \\ 1,2,4 Faculty of Law, Universitas Negeri Semarang, Indonesia \\ ${ }^{3}$ Head of General Affairs and Planning, Lerep Village, Indonesia \\ Corresponding author: fadhilahputri@students.unnes.ac.id
}

\begin{abstract}
This study aims to provide another alternative in resolving conflicts in Lerep Village which is called the District Court (Peradilan Desa). The village court aims to help resolve conflict problems in Lerep Village so that there is no accumulation of cases in the surrounding District Courts. Village justice is carried out by familial mediation between the person in dispute with the head of the local hamlet and the village head. The decisions given are in the form of suggestions from the hamlet head and village head which are not binding. District justice (Peradilan Desa) is a win-win solution to the conflict in Lerep Village. However, the implementation of this District court still has shortcomings. One of them is the district court does not yet have a reference for regulations in its implementation. Another deficiency is the lack of knowledge in the legal field of the parties acting as intermediaries, such as the hamlet head and village head. The research method used in this research is legal research, legal research is often referred to as doctrinal or normative. Normative legal research examines principles, numbers, concepts, rules, laws and regulations, research decisions, agreements and doctrines that are placed by law as a norm system by examining library studies. The conclusion in this study is that specific regulatory references are needed to regulate the running of village courts. And there must be trainings to provide basic knowledge to the parties concerned.
\end{abstract}

Keywords: Conflict Resolution; District Courts; Mediation; Procedural Law.

\section{How to cite:}

Wahanisa, R., Lestari, D., Rahman, M. A. M., \& Putri, F. R. A. (2021). How Do Villagers Solve Their Legal Problems? A Study of District Court (Peradilan Desa) for Dispute Settlement Process. Indonesian Journal of Advocacy and Legal Services, 3(2), 233-244. https://doi.org/10.15294/ijals.v3i2.45843 


\section{A. Introduction}

The written constitution in Article 1 Paragraph (2) of the 1945 Constitution of the Republic of Indonesia states that the state of the Republic of Indonesia as a state of law, the consequences of a state of law, so that everything in carrying out the life of the nation and state must be based on law, both law which is in the most hierarchical level. high or the lowest. However, if it focuses solely on a written constitution, it is not appropriate because a constitution is interpreted in two senses, namely, a written constitution and an unwritten constitution, a written constitution is an elaboration of the constitution in the narrow sense, while an unwritten constitution is defined as a constitution in a broad sense. ${ }^{1}$ The Constitution was not written very much compared to the constitution is not written, but the existence of a written constitution must remain the same confession with a written constitution, the constitution becomes a guideline for the bang s a Indonesia in running the nation and the landless water which regulates the behavior of the government and people. With the constitution can serve as guidelines for achieving the ideals of the Indonesian nation and avoid the conflicts and divisions, but certainly in the running life of the nation is certainly not always smooth because in society there is a conflict as part of a si stem social necessitating a resolution of the conflict. ${ }^{2}$

Broadly speaking, conflict resolution is carried out by litigation and non-litigation, while litigation settlement is carried out by legal channels using court as regulated in the written constitution in article 24 concerning justice and its derivative regulations, while non-litigation settlement is carried out outside the court as regulated in the written constitution. article $18 \mathrm{~B}$ and its derivative regulations. ${ }^{3}$ Settlement through litigation and nonlitigation channels certainly has advantages and disadvantages in resolving conflicts, the advantages of conflict resolution through courts are that it has the power to force the guilty party to obey the verdict of the court, but the drawback is that it takes a long time in the settlement process. high costs, results that make one party have to suffer losses and sometimes justice is not obtained.4 However, the advantages of resolving problems through nonlitigation channels are that all parties are satisfied with the recommendation that is a win-win solution, besides that the cost of the case is cheap and is

Wheare KC, Modern Constituency, (Oxford: Oxford University Press, 1975), p. 3. Atmadja I Dewa Gede, Hukum Konstitusi, (Malang: Setara Press, 2012), p 13.

Adi Susanti Nugroho, Benefits of Mediation as an Alternative to Dispute Resolution, (Jakarta: Kencana, 2019), p. 25.

4 Fiadjoe Albert, Alternative Dispute Resolution: A Developing World Persprective, (London: Cavendish Publishing Limited, 2014), p. 19. 
almost non-existent, reconciliation between the two warring parties is very fast and the resolution is not It takes a long time, but besides this there is a drawback that is not having the force to force all parties to comply with the results of the settlement and sometimes it is opposed by one of the parties. If the parties do not comply with the results of dispute resolution or do not find peace, they can submit a resolution of the problem through the court. ${ }^{5}$

Courts in Indonesia cannot be separated from the influence of occupation the Netherlands, during the Dutch colonial occupied territories Indonesia to master a variety of natural resources, in addition to mastering the natural wealth of the colonial government the Dutch East Indies also apply rules to regulate the process control of its natural resources. Among them were the making of special rules to control Indonesian colonies, including by implementing the Wetboek Van Strafrecht Vor Netherlands Indishce which was an adoption of Weetboek Van Strafrect which was the Dutch criminal code book and brought Burgelick Weetboek and Weetboek Van Kophandel to regulate the process of occupation and control of natural resources. in Indonesia. However, apart from making legal rules, of course, implementing regulations are needed that serve as guidelines for implementing the material law, including the Het Herizene Inlandsh Indische Regalement. Of course, the existence of material and formal laws is not enough, so that a court is needed as a forum to apply the two rules. ${ }^{6}$ Court of the Dutch government there are five types of justice among Court of Gubernemen, judiciary indigenous or customary justice, the justice's king, religious courts, and village justice. The village court is a lower-level court that is different from the traditional court, the most fundamental difference lies in the implementation and the judges in the court. Judges in village courts are village heads or hamlet heads with problem solving using deliberation to reach consensus, while customary courts who become judges are customary stakeholders and their reference refers to customary law. ${ }^{7}$ The scope of the village court itself only covers the area of a village and what can be resolved are minor problems.

After the amendment to the 1945 Constitution of the Republic of Indonesia, legal changes, and legal developments from time to time have increased, including the existence of an unwritten constitution which is increasingly popular in Indonesian society, this can be seen by the existence

Arief, Barda Nawawie, Aspects of Penal Mediation Policy in Out of Court Dispute Resolution. (Semarang: National Seminar, Diponegoro University's Doctor of Law Program, 2007), p 8.

6 Nasution Bahder Johan, History of the Development of Judicial Power in Indonesia, (Journal of Innovative Volume VII Number III, 2014), p. 14.

7 Ibid., p. 16. 
of various customary institutions that the government has begun to glance at to organize. and protected. One of these customs regulates the settlement of disputes among indigenous peoples, but besides that the principle of deliberation and consensus that has long existed in Indonesian society continues to exist and is increasingly popular in making decisions.

The existence of Article 18 B and Article 28 I of the 1945 Constitution of the Republic of Indonesia provides an opportunity for villages as the lowest government institution to carry out their own government. One of the tasks of the village government is to create order and security in the community, then to create this order requires an effort to achieve these goals through law enforcement. One of the ways to create order and security in the village community can be done by using village autonomy. ${ }^{8}$ With the special status that a village has in the form of autonomy, it should be able to create independence and new innovation in order to create security and order for the people of a village through the formation of village regulations or the equivalent to create a village court as an effort to resolve disputes outside the court which becomes an alternative that needs to be done to create justice for the parties and streamline the cases that have accumulated in court. However, the concept of village justice in question has never been realized, so it becomes a question for the author regarding the legal basis and model of village justice that can be made by the village? And what is the existence of the village court judges, namely the village head, in implementing the village court? Therefore, it is necessary to have a study to find and answer questions from the author.

\section{B. Method}

This research is legal research, this legal research is often referred to as doctrinal or normative. Normative legal research examines principles, numbers, concepts, rules, laws and regulations, research decisions, agreements and doctrines that are placed by law as a norm system by examining librarian studies. 9 The approach used in this research is the statutory approach to study the juridical existence and history of village courts in legislation, while the conceptual and historical approaches are used to study concepts that are relevant to the object of study. The data in this study use primary data and secondary data as well as non-legal materials, by

\footnotetext{
8 Widjaja AW, Village Government and Village Administration according to Law no. 5 of 1979 (as a review), Jakarta: Raja Grafindo Persada, 1996), p. 28.

9 Marzuki, Peter Mahmud. Legal Research, (Jakarta: Kencana Prenada Media Group, 2009), p. 59.
} 
means of the necessary information citation techniques by browsing literature through libraries and digitally. The data collected is then validated and then processed and analyzed qualitatively to produce a descriptive study in a narrative form.

\section{Result And Discussion}

\section{Village Jurisdiction Concept: Comparing Practices}

Law as a rule to regulate human beings should be used in an attempt to achieve justice, $\mathrm{k}$ e uncertainties and usefulness of law so as to achieve this as an order of values and norms that exist and thrive within the community needed an embodiment in the system of norms in the life of the Indonesian people where this can be done through the implementation of religious norms, norms of decency, norms of decency and legal norms themselves. Law itself is an order that seeks to influence all human behavior to meet the needs and purposes by way of a fair proportional morally set a justified. However, shift understanding about the law as moral values as well as an important element for achieving justice, benefit, and the rule of law, giving rise to several problems such as disputes between ordinary citizens in the village, usually such as land disputes, disputes between citizens and others.

\section{The Village Concept in the United States}

Law as a rule to regulate human beings should be used in an attempt to achieve justice, $\mathrm{k}$ e uncertainties and usefulness of law so as to achieve this as an order of values and norms that exist and thrive within the community needed an embodiment in the system of norms in the life of the Indonesian people where this can be done through the implementation of religious norms, norms of decency, norms of decency and legal norms themselves. Law itself is an order that seeks to influence all human behavior to meet the needs and purposes by way of a fair proportional morally set a justified. However, shift of understanding about the law as basic values as well as an important element for achieving justice, benefit, and the rule of law, giving rise to several problems such as disputes between ordinary citizens in the village, usually such as land disputes, disputes between citizens and others.

Some of the village concepts that can be used as a concept reference, one of which is from various states in the United States. In the United States, many villages are partly recognized as incorporated villages and without a legal status (corporated villages). The term village in the United States has a different meaning in each state. In the United States, most of these villages are no longer considered important. Instead, the village is only a place for several communities which are used as a special meeting place for tourism 
objects. In many states, the term desa (villages) is only associated with communities that are relatively small and do not have a legal status. The term village is associated with a certain form of municipal government, which is smaller than a city, both geographically and in authority, but has the status of a legal entity (incorporated). For example, in some states, such as New York, Wisconsin, or Michigan, what is called a village is an "an incorporated municipality", usually a single town or civil township.

In the state of Wisconsin, by law, the village is always separated from the city that legalizes it. Residents pay taxes and have the right to vote in village head elections. There is no limit on the number of residents. In states like Wisconsin, by law, the village is always separate from the city that authorizes it. In Maryland, for example, what is called a village can be a locality incorporated town or a particular district of taxpayers. Another example is the Village of Friendship Heights. Meanwhile, in the states of the former old-town cities of the New England era, the so-called villages were always associated with centers of population or commerce, including the city center, a kind of town square. Take the village of Hyannis in the middle of the small town of Barnstable, Massachusetts.

\section{Village Concept in Indonesia}

In Indonesia, there are around 73,000 villages and around 8,000 subdistricts. ${ }^{10}$ These villages can be divided into two, namely ordinary villages and traditional villages. Therefore, there are two distinct concepts of society, namely (i) rural communities, and (ii) indigenous peoples. In the General Elucidation of Law Number 6 of 2014 concerning Villages, it is described as follows:

"The village or what is called by another name has characteristics that are generally accepted throughout Indonesia, while the Traditional Village or what is called by other names has different characteristics from the Village in general, especially because of the strong influence of adat on the local government system, management of local resources, and the socio-cultural life of the Village community. In principle, the traditional village is a legacy of a local community governance organization that has been preserved from generation to generation which is still recognized and fought for by the leaders and community of the Traditional Village so that it can function to develop welfare and local socio-cultural identity. The Traditional Village has the right to the origin of the Village since the

Traditional Village was born as an original community in the midst

\footnotetext{
${ }^{10}$ Law No.6 of 2014 concerning Villages
} 
of society. Desa Adat is a customary law community unit that has historically had territorial boundaries and cultural identities formed on a territorial basis which is authorized to regulate and manage the interests of the village community based on their rights of origin.

According to Law No.6 of 2014 concerning Villages, the village government has the authority to enact Village Regulations with the joint approval of the Village Representative Body. Thus, in the village, it is determined that there is a village regulation which is recognized as a form of official statutory regulation. Village communities are structured in the context of the local government legal regime. The village government unit is the smallest unit in the regional government organizational structure.

As a result of the development of information and communication technology, villages around the world will experience globalization. One of the impacts of village globalization is the universalization process of ideal values in the common life of humankind, including in villages around the world. In order to promote the development of a civilized urban society, the organizing of the villagers requires an institutional process that is more adequate than the current situation. These village community institutions must be functioned effectively to encourage and drive the wheels of development towards progress in all areas of the life of the villagers. Villages and village communities need to be empowered and strengthened into civil society supported by systems and institutional structures that ensure the autonomy of their communities to be creative and innovative.

The piling up of cases in the District Court is one of the reasons behind the initiation of the Village Court in order to unravel the accumulation of cases in the District Court. The Village Court is one of the manifestations of a village that is affected by globalization and is aimed at creating a civil society and a village with urban civilization. ${ }^{11}$

Village justice is an alternative dispute resolution in the village which is carried out by means of mediation. The existence of this village court is to unravel the accumulation of cases in the District Court. So that the initiation of this village court can become an institution that can support and provide village functions in order to encourage the village to develop into a civilized society.

11 Jimly Ash-Shiddiqie, Ideas of a Social Constitution, (Jakarta: Pustaka LP3ES, 2015) p.362 


\section{Existence of Village Chairman as Judge}

The description of the concept of village justice above becomes a reference for the direction of dispute resolution which is served by members of the village court. Village Chief Judge of the village court has the authority contained in the legislation, $\mathrm{k}$ raft authority of the village chief $\mathrm{t}$ erdapat in chapter 200 -202 Act No. 32 of 2004 concerning regional government which states explicitly that the village government consists of the village head and village officials as well as the village consultative body (BPD). The duties and powers of the village head themselves are regulated in a derivative regulation from the regional government law in PP no. 72 of 2005 in article 14 paragraph (1) and (2) which states:

1) The Village Head has the task of carrying out government, development and social affairs;

2) In carrying out the tasks referred to in paragraph (1) the Village Head has the authority;

a. Leading the implementation of village governance based on policies established with the BPD;

b. Submit a draft village regulation;

c. Establish village regulations that have received joint approval from the BPD;

d. Prepare and propose draft village regulations regarding the Village APB and stipulate jointly with the BPD;

e. Fostering village community life;

f. Fostering the village economy;

g. Coordinating participatory village development;

h. Representing the village inside and outside the court and can appoint a legal representative to represent in accordance with statutory regulations; and

i. Carry out other authorities in accordance with statutory regulations. Meanwhile, the obligations of the village head are explained in the next article, namely article 15 paragraphs (1) and (2), which states:

(1) In carrying out the duties and authorities as referred to in Article 14, the Village Head has the following obligations:

a. Upholding and practicing Pancasila, implementing the 1945 Constitution of the Republic of Indonesia and maintaining and maintaining the integrity of the Unitary State of the Republic of Indonesia;

b. Improve community welfare;

c. Maintain public order and order;

d. Carry out a democratic life; 
e. Implementing the principles of village governance that is clean and free from Collusion, Corruption and Nepotism;

f. Maintain working relationships with all village government partners;

g. Obey and enforce all laws and regulations;

h. Carrying out good village government administration;

i. Implement and be accountable for village financial management;

j. Carry out the affairs that fall under the authority of the village;

k. Reconciling the community in the village;

1. Developing communities and villages;

m. Fostering, protecting and preserving social, cultural and customs values;

n. Empowering the community and institutions in the village; and

o. Developing the potential of natural resources and preserving the environment

(2) Apart from the obligations as referred to in paragraph (1), the Village Head has the obligation to provide a report on the administration of village administration to the Regent/Mayor, provide a report on accountability statements to the $\mathrm{BPD}$, and inform the village administration report to the community. ${ }^{12}$

One of the responsibilities of the village head regarding resolving community disputes needs to be studied in detail by referring to the concept that the village head is the mediator in every existing village community problem. Their position as a village chief judge to reconcile disputes light that is in rural communities are expected to contribute to peace to preserve harmonisation and patterns of social interaction between the villagers. The village head as mediator in the peace may use discretion or policy of the executive branch in order to realize public services to people who refer to the legislation.

\section{Conclusion}

The existence of Village Courts in Indonesian society is well accepted and has been running from the pre-independence era to the reform era, village justice itself can be the main alternative for resolving disputes because it is fast, low cost, even there is no case fee and is a win-win solution that can accepted by all the disputing parties and can quickly make the parties interact again. The

12 Nainggolan, Samuel Dharma Putra, Position of Village Head as Peace Judge (Ubelaj Journal Volume 3 Number I, 2018), p. 9. 
implementation of the village court itself is led and chaired by a village head who is trusted by the community to help reconcile the parties so that an agreement is reached from the parties. A right, however, the village court arrangements in the laws and regulations are still very abstract so that implementing village justice in every village is still not going well. The presence of a village court as an alternative for dispute resolution is a breath of fresh air for law enforcers because it can reduce cases that go to court, but there are no specific legal rules governing village justice so it is hoped that the Village Court Bill will be presented in the near future. The village head as a peace judge at the village court is the right thing because he has the support of the community and is guaranteed in statutory regulations. Although the positions of judges of peace there are problems guess understanding of the law is the village head related scientific field of law which may affect the judicial process, so it is recommended to be given training to village heads and members of village justice related procedures for solving problems.

\section{E. Acknowledgments}

None.

\section{F. Declaration of Conflicting Interests}

The authors states that there is no conflict of interest in the publication of this article.

\section{G. Funding}

None.

\section{H. References}

Adi Susanti Nugroho (2019) Benefits of Mediation as an Alternative to Dispute Resolution, Jakarta: Kencana.

Arief, Barda Nawawie (2007) Aspects of Penal Mediation Policy in Out of Court Dispute Resolution. Semarang: National Seminar, Diponegoro University's Doctor of Law Program.

Asshiddiqie, Jimly (2007) Principles of Indonesian Constitutional Law, Post-Reformation. Jakarta: Buana Popular Science.

Asshiddiqie, Jimly (2015) Ideas of a Social Constitution, Jakarta: LP3ES Library. 
Atmadja I Dewa Gede (2012) Constitutional Law, Malang: Equivalent Press.

Fiadjoe Albert (2014) Alternative Dispute Resolution: A Developing World Persprective, London: Cavendish Publishing Limited.

Marzuki, Peter Mahmud. (2009) Legal Research, Jakarta: Kencana Prenada Media Group.

Nainggolan, Samuel Dharma Putra (2018) Position of Village Head as Peace Judge, Ubelaj Journal Volume 3 Number I.

Nasution Bahder Johan (2014) History of the Development of Judicial Power in Indonesia, Innovative Journal Volume VII Number III.

Wheare KC (1975) Modern Constitution, Oxford: Oxford University Press.

Widjaja, AW, (1996) Village Administration and Village Administration According to Law no. 5 of 1979 (as a review), Jakarta: Ra j a Grafindo Persada.

1945 Constitution

Law No. 6 of 2016 concerning the Village

Law No. 32 of 2004 concerning Regional Government

PP No. 72 of 2005 concerning the Village 
R. Wahanisa, D. Lestari, M. A. M. Rahman, \& F. R. A. Putri

\title{
Truth never damages a cause that is just.
}

\author{
Mahatma Gandhi
}

